\title{
Fındıkta kabuklu ve iç meyve kusurları
}

\author{
Saim Zeki BOSTAN 1 \\ ${ }^{1}$ Ordu Üniversitesi, Ziraat Fakültesi, Bahçe Bitkileri Bölümü, Altınordu/Ordu
}

Alınıș tarihi: 7 Kasım 2019, Kabul tarihi: 17 Aralık 2019

Sorumlu yazar: Saim Zeki BOSTAN, e-posta: szbostan@hotmail.com

$\ddot{0} \mathbf{z}$

Findıkta gerek kabuklu ve gerekse iç meyvede oluşan kusurlar telafisi mümkün olmayan sonuçlara sebebiyet verebilmektedir. Findıkta kusurlar hem kabuklu hem de iç meyvede görülebilmektedir. Bu kusurların başlıcaları kahverengi leke, çıtlak meyve, küçük meyve, çoklu meyve, boş meye, eksik (abortif) ve buruşuk iç, büyük göbek boşluğu, çift iç, liflilik, siyah uçlu iç, küflü iç ve böcek zararlı iç’tir. Bu kusurların ve oluşum nedenlerinin bilinmesi ve sonra bunlara karșı önlemlerin zamanında alınması hem üretici, hem sanayici hem de tüketiciler bakımından son derece önemlidir. Öncelikle ekolojiye göre çeşit seçimi, uygun tozlayıcı çeşit seçimi, doğru fidan kullanılması, doğru yer seçilmesi, doğru dikim ve terbiye sisteminin uygulanması gibi konulara da dikkat edilmelidir. Diğer tarafatan, düzenli, bol ve kaliteli ürünü elde etmek için ağaçların yıl boyunca bakımlarının yerinde ve zamanında yapılması gerekmektedir.

Anahtar Kelimeler: Fındık, Meyve, İç, Kusur

\section{Nut and kernel defects in hazelnut}

\begin{abstract}
Both the nut and the kernel defects in hazelnuts can cause irreparable results. Defects in hazelnuts can be seen in both nut and kernel. The main defects are brown stain, split sutures, small nut, multiple nut, empty nuts, poor filled nuts (abortive kernel) and shrivelled kernel, large internal cavity, double kernels, fiberiness on kernel, black-tipped kernel, moldy kernel and insect damaged kernel. It is extremely important for both the producers, the industrialists and the consumers to know these
\end{abstract}

defects and their causes and to take timely measures against them. First, attention should be paid to issues such as selection of varieties according to ecology, selection of suitable pollinator varieties, use of correct sapling, selection of right place for orchard, application of correct planting and training system. On the other hand, in order to obtain a regular, abundant and quality product, the trees must be maintained on-site and on time during the year.

Key words: Hazelnut, Nut, Kernel, Defect

\section{Giriş}

Fındıkta sağlam meyve oranının fazla olması bir taraftan yüksek verim için üreticiler açısından olmazsa olmaz şart iken, diğer taraftan hem kabuklu hem de iç meyvedeki kusurların az olması iç ve diş pazar istekleri yönünden önem arz etmektedir. Sağlam meyve oranı ile kabuklu ve iç meyve kusurları çeşit, ekoloji, tozlanma ve döllenme koşulları, beslenme koşulları ve kültürel ve teknik uygulamalar gibi birçok faktör etkisi altında ortaya çlkabilmektedir.

Dünyada fındıklar ya kabuklu ya da kırıldıktan sonra iç olarak pazarlanmaktadır. Her iki formda da ürünler farklı şekillerde işlenerek piyasaya sunulabilmektedir. Her iki pazara yönelik olan çeşitler de farklıdır. Kabuklu halde pazara sunulacak fındıkların üniform irilik ve şekle, en az düzeyde tüylülüğe, canlı renge, parlaklığa, açık kahverengi bir renge veya açık kahverengi bir zemin üzerinde koyu çizgilere sahip olması ve çizik, çıtlak veya kahverengi leke gibi kabuk kusurlarına sahip olmaması istenilmektedir. Yine kabuklu halde satılan fındıkların büyük ve çekici olması gerekir. Natürel iç fındıklarda ise aynı ve küçük-orta irilikte olması, 
gevrek yapıda olması, yuvarlaklık (kurutmada buruşukluğun olmaması vs), buruşuk veya lifli olmayan pürüzsüz bir zar, açık renklilik ve diğer kusurlardan yoksun olması gibi özellikler aranmaktadır (Mehlenbacher, 1991; Thompson ve ark., 1996). Her ne kadar natürel iç findıklara olan talep mevcut olsa da, bunların çoğu beyazlatılmış olarak satılır. Her iki pazar için çeşitlerin iyi dolgun, ince kabuklu, yuvarlak şekilli, çok az kusurlu ve uzun raf ömrüne sahip olması gerekir (Mehlenbacher, 1991).

Natürel iç olarak pazarlanan çeșitlerde ağacın toplam kabuklu meyve verimi iç meyvenin verim etkinliği (gövde kesit alanının santimetrekaresi başına düşen sağlam içlerin ağırlığı) kadar önemli değildir. Bu parametre nispi ağaç büyüklügü, sağlam meyvelerin iç oranı ve sağlam içlerin oranında dikkate alınmaktadır. Sağlam içlerin oranı, değişik kusurlu iç meyve ve boş meyvelerin farklı oranları dolayısıyla, önemli ölçüde genotiplere ve yıllara göre değişim gösterir (Thompson ve ark., 1996).

Kabuklu ve iç meyve kusurları birçok fındık çeşitlerinde görülen ciddi problemler olup bunların oranlarını azaltmak da ıslah programlarının bir amacı olmuştur. Boş meyve, kahverengi leke, çift iç, küflü iç, siyah uçlu iç, buruşuk iç ve eksik içli meyveler bunlardan birkaç tanesidir. Bu kusurlar verim ve kaliteyi sınırlandırır, üretici gelirlerini azaltır ve işleme maliyetlerini artırır. Dünyanın önde gelen çeşitlerinin çoğu bu kusurlardan bir veya daha fazlasindan muzdariptir (Mehlenbacher ve ark., 1993).

Büyük meyveler kabuklu olarak, küçük meyveler de kırılarak iç halinde tüketilmeye daya uygundurlar. Büyük olan meyveler kuruduğunda buruşuk içe sahip olur. Küçük meyvelerin içleri büyüklerine göre daha dolgun durumdadırlar. İriliğin yanında, kabuklu meyvenin albenisinin de iyi olması istenir. Canlı kahverengine ve az tüylülüğe sahip olmalıdır. Çoğunlukla meyvenin ucuna doğru çıkan sert, kısa tüyler, mekanik hasat sırasında kir toplar ve ağartmadan sonra bile donuk bir görünüme neden olur. İnce kabuklu çeşitlerin randımanı yüksek olmaktadır. Tüketici ve işleyiciler böyle fındıkları tercih ederken, bu durum üretici için problem oluşturabilmektedir. Bunun nedeni de ince kabuklu çeşitler kuş ve kemiriciler için cazip olabilmekte, bu da önemli ürün kaybına sebep olabilmektedir. Ayrıca böyle meyveler mekanik hasat sırasında kırılmalara daha fazla maruz kalabilmekte ve kuruma esnasında da kabukları çatlayabilmektedir. İç fındıklarda temizlik önemlidir. Fındık içi büyüdükçe iç yumurtalık duvarının hücrelerini baskılar. Kuruduğunda zar olarak adlandırılan böyle dokular kabuğa bağlı kalır ve için temiz olmasını sağlar. Zarın çok olması hem albenisini olumsuz etkiler hem de tadı azaltır. İster kabuklu ister iç halde tüketilsin, doğal olarak zardan ari içler arzu edilir (Lagerstedt, 1975).

$\mathrm{Bu}$ makalede findık üreticisi, satıcısı ve işleyicisi açısından önem arz eden kabuklu ve natürel iç fındıkta görülen kusurlar ile bunların oluşum nedenleri üzerinde durulmuştur.

\section{Kabuklu meyve kusurları}

Kabuklu halde pazarlanan fındıklar kabuk yüzeyinin $\%$ 25'inden fazlasını etkileyen lekelerden arınmış sağlam, temiz kabuklara sahip olmalıdır. İçler kabuk içinin en az \% 50'sini doldurmalı, buruşmamalı, küften veya böceklerden zarar görmemelidir. Kabuklu meyveler, tüm meyve için $\% 12$ 'den az veya iç için \% 7'den daha az bir nem içeriğine sahip olmalıdır. Meyvelerin çoğu (en az \% 90'ı) belirtilen çeşitlerden olmalıdır. Meyveler büyük olmalıdır (Anonim, 2016).

\section{Kahverengi leke}

Kahverengi leke, nedeni bilinmeyen ciddi bir bozukluk olup boş meyve oluşumuna sebep olur. Bu kusur düzensiz olarak ortaya çlkar ve ciddi ürün kaybına neden olabilir. Aşırı olması durumunda ürünün önemli bir kısmı kaybolur. Bakımsız bahçelere göre bakımlı bahçelerde kahverengi leke daha yaygındır. Çeşitler arasında bu bakımdan bariz farklılıklar vardır. Belli yıllarda ve belli ağaçlarda etkili olabilen bu bozukluğun, bir böcek veya patojen ile ilgisi kurulamadığından, fizyolojik bir problemden kaynaklanabileceği düşünülmektedir. Kalıtım derecesi sıfıra yakındır. Belirtisi ise meyvenin kenarı veya apikal ucunda kahverengimsi bir sivı görünmesidir (Mehlenbacher, 1991; Mehlenbacher ve ark., 1993).

Kahverengi leke bozukluğu kabukta başlayıp çapı 3 ila $4 \mathrm{~mm}$ arasında gelişmekte olan iç meyveyi çevreleyen süngerimsi dokuya doğru ilerler. İlk bașta, vasküler demetler arasındaki alanlardan kahverengi sulu bir madde çıkar, kabuk lekelenir ve tüm iç doku sonunda kahverengi ve sulu olur. $\mathrm{Bu}$ bozukluk ilk olarak kabuk sertleştiğinde görülür (Germain, 1994). Temmuz'un başlarında kenarlarında kahverengi lekeleri görünen meyveler genellikle temmuz ve ağustos aylarında dökülür. Bu 
meyvelerin çoğunun içi ya boștur ya da eksik içleri az gelişmiştir (Anonim, 2002).

Azotlu gübre, bor spreyleri, dip sürgününü kontrol eden spreyler, kireçleme ve budama gibi bazı kültürel uygulamalar kahverengi leke miktarını artırmaktadır. Kahverengi lekeli çotanakların zurufları normal zuruflardan daha düşük kalsiyum içeriğine sahiptir. Kahverengi lekeli fındığın özü normal findık özünden daha yüksek bir azot seviyesine ve daha düşük bir bor seviyesine sahiptir (Stebbins, 1984; Germain, 1994).

Genetik ve kültürel faktörlerin dışında, bazı iklimsel parametreler de kahverengi bozukluğunu artırabilir. Gübrelemeden hemen sonraki düşük sicaklık ve yüksek yağışın, kahverengi lekeye hassas findıklarda bu oranı artırmakta ve haziran ayındaki gübrelemeden sonraki ilk iki hafta boyunca haftalık ortalama maksimum sicaklıkların $21{ }^{\circ} \mathrm{C}$ 'nin altında olması durumunda da kahverengi lekeli findık yüzdesi yükselmekte, bu değerin altındaki günlük maksimum sicaklıklar ise etki etmemektedir (Latorse (1981).

\section{Çıtlak meyve}

Bazı çeşitlerde zayıf süturlar vardır ve bundan dolayı birleşme noktasında çatlaklar gelişir. $\mathrm{Bu}$ süturlar ayrıldığında, içlerin uçları kararabilir ve genellikle bunlar küflenebilir (Anonim, 2016). Kabuklu meyvenin dolgun olması irilik bakımından istenmekte fakat kabukların kalın olması ve yüksek oranda çitlama göstermesi durumunda daha sonradan siyah uçlu içlerin olușmasına neden olmaktadır (Sathuvalli ve ark., 2010).

Çıtlak meyve kusurunun daha ziyade bir çeşit özelliği olduğu ve bu eğilimin de ekoloji, beslenme ve iç dolgunluğu ile daha çok ortaya çıktığı belirtilmiştir (Turan, 2017). Bu durum 'Tombul', 'Palaz' ve 'Foșa' çeşitlerinde sık görülürken, 'Çakıldak' ve 'Allahverdi' çeşitlerinde hemen hemen hiç görülmez. Özellikle döllenme ile hasat arasında iç gelişiminin hızla gerçekleştiği dönemde meydana gelen aşırı yağışlar iç iriliğinin artmasına ve çıtlak meyve oluşumuna sebep olmaktadır. Kabukta oluşan açıklıktan bazı fungus türlerinin nüfuz etmesi sonucunda acılaşma ve küflenme de meydana gelmektedir (Balık, 2019).

Yapılan farklı çalışmalarda çıtlak meyve oluşumu da araştırılmıştır. 'Tombul' 'Palaz', 'Sivri', 'Çakıldak', 'Kalınkara', 'Yuvarlak Badem' ve 'Acıfındık' standart çeşitleri ile 'Hanımfındı̆̆ı', 'Yerlifındık' ve 'Cevizfındığı' yerel çeşitlerinde en fazla çıtlak meyve oranının \% 16 oranıyla 'Tombul' çeşidinde olduğu belirlenmiștir (Beyhan ve Demir, 2001).

'Çakıldak', 'Palaz' ve 'Tombul' çeşitlerinde yürütülen bir çalıșmada da, çıtlak meyve oranı meyvelerde limonlașma ve ekși limonlu iç oranının artmasına neden olduğu ifade edilmiștir (Turan, 2017).

Findıkların zuruflarından patozla ayıklanması durumunda çıtlak meyve oranı, önemsiz seviyede, patozla ayıklananlarda daha fazla olmuştur (Akar ve Bostan, 2018).

Tozlayıcı çeşitlerin ve serbest tozlanmanın da çıtlak meyve oluşumu üzerine etkisi önemli olup bu durum çeşitlere, melezleme kombinasyonlarına ve yıllara göre değișebilmektedir (Balık, 2019).

\section{Küçük meyve}

Kabuklu küçük meyveler, normal büyüklükteki meyvelerin en fazla 2/3'ü kadar ya da bundan küçük olan meyvelerdir (Bostan, 1997a). Suyun eksikliği, iç gelişimi sırasında eksik ve buruşuk içlerin oluşumuna neden olurken, kabuklu meyve gelişimini de azaltır (Mehlenbacher ve ark., 1993). Diğer taraftan, küçük meyve oluşumunu çotanaktaki meyve sayısı da etkileyebilmekte ve bu durum çeşitlere göre değișebilmektedir. Nitekim 'Tombul' çeşidinde bir ilişki belirlenemezken, Sivri ve Palaz çeşitlerinde çotanaktaki meyve sayısı arttıkça küçük meyve oluşumu da artmıştır (Bostan, 1997a).

Yapılan bir çalışmada, 'Palaz' çeşidinde küçük meyve, boş meyve, eksik iç ve buruşuk iç kusurlarının en yaygın kusurlar olduğu ve küçük meyve oranının \% 0.98 ile \% 13.85 arasında değiștiği belirlenmiştir (Bostan ve İslam, 1999).

Diğer çalışmalarda, 'Çakıldak' çeşidinde küçük meyve oranının rakıma göre değişiminin önemli olmadığı ve küçük meyve oranı ile verim arasında negatif önemli ilişki olduğu (Bozkurt ve Bostan, 2018); 'Tombul' çeşidinde küçük meyve oranının sulamaya göre değişmediği ama iç kusurlarının sulanan ağaçlarda daha az bulunduğu (Külahçilar ve ark., 2018); küçük meyve oranının 'Tombul' ve 'Palaz' çeşitlerinde gün boyu güneşli bahçelerde daha yüksek olduğu ama istatistik olarak önemsiz çıktığı belirlenmiştir (Şen ve Bostan, 2020).

\section{Çoklu meyve}

Çoklu kabuklu meyve nadiren gözüken bir kusur olup birden fazla kabuklu meyvelerin birbirine yapışık olma durumudur (Şekil 1).

Gözlemlerimize göre, yaz periyodunda havaların aşırı sıcak gittiği kurak dönemini takip eden yılda 
daha fazla gözükmektedir. Yine gözlemlerimize göre çeşitlere göre de değişen bir özelliktir. Böyle meyveler normal meyvelere göre anormal şekilli olmaları ve daha küçük olmaları nedeniyle verim ve kalite düşüklüğüne sebep olabilmekte, diğer taraftan da böyle meyvelerin normallerinden aylklanması için fazladan bir iş gücü gerekmektedir.

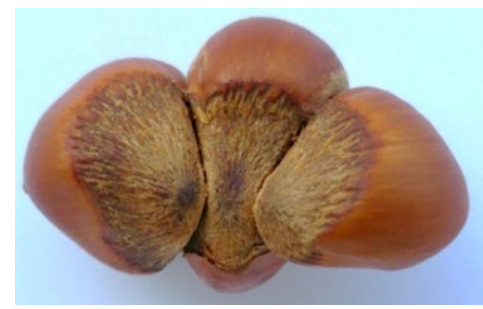

Şekil 1. Findıkta çoklu meyve

\section{İç meyve kusurları}

Natürel iç olarak pazarlanacak meyvelerin kırılmaları sırasında içlerin parçalanmaması için kabukla iç arasında yeterli boşluğun olması ve neminin \% 6'yı geçmemesi gerekir. Bunun yanında, buruşuk, küflü, çürük, kötü kokulu, hasarlı olmamalıdır. Yetiştiriciler için, hasatta kabul edilebilir meyve kalitesinin elde edilmesi, hasat sonrası temizleme ve işleme sistemlerinin kusurlu meyveleri ayıklama yeteneğine bağlıdır. Buruşuk içler de dahil olmak üzere, boş meyveler ve eksik içli meyveler temizleme sirasinda veya kuruduktan sonra ayrılabilir. İç kusurları kabuk kırılıncaya kadar belli olmaz, bu nedenle kabuklu ticaret için fındıklarda çok az iç kusuru olması gerekir (Anonim, 2016).

İç kusurları arasında küflü içler, siyah uçlar, buruşuk içler, çift içler, abortif içler, testa üzerinde kahverengi çizgiler veya lekeler, göbek boşluğunun iç yüzeyindeki dokunun kahverengileşmesi ve iç yüzeyinde çökük lekeler bulunur (Thompson ve ark., 1996).

Fındık tohumu yenilen bir meyve türü olduğundan, normal tohumlu meyve elde edebilmek için döllenme ve embriyo gelişmesi zorunludur. Döllenmeden sonra embriyo gelişiminin herhangi bir aşamasındaki aksaklık ise meyvelerin küçük ve kusurlu içli olmasına neden olur. Bütün bunlar, üründe randımanı ve verimi olumsuz yönde etkilemektedir (Beyhan, 1995). Bozkurt ve Bostan (2019) 'Çakılldak' fındık çeşidinde sağlam iç oranının ise rakımlara göre değişiminin önemli olduğunu ve en yüksek sağlam iç oranının $400 \mathrm{~m}$ ve $600 \mathrm{~m}$ rakımdaki bahçelerde, en düşük oranın ise $800 \mathrm{~m}$ rakımdaki bahçelerde olduğunu belirlenmişlerdir. Kusurluluk oranları farklı çeşitlerde farklı oranlarda olabilmekte ve bazı kusurların değişiminin de çeşitlere göre önemli olduğu görülmektedir (Akçin ve Bostan, 2018). Diğer taraftan, 'Çakıldak' çeşidinde bakımlı bahçelere göre bakımsız bahçelerde kusur oranlarının daha yüksek olduğu belirlenmiştir (Yaman, 2019).

\section{Boş meyve}

Normal bir içe sahip olmayan kabuklu meyveler olarak tanımlanan boş meyveler bazı çeşitlerde önemli miktarda ürün kaybına neden olur. Bazı klonlarda bu oran yüksek olabilmektedir. Boş meyve frekansına çevresel faktörler de önemli etki etmektedir. Boş meyveler, kusurlu embriyo keseleri, cansız yumurtalar, döllenme yetersizliği veya çeşitli gelişim evrelerinde embriyo aborsiyonlarından kaynaklanabilir (Thompson ve ark., 1996). Boș meyveler, tozlanma yumurtalığın gelişimini teşvik ettiği fakat için normal olarak gelişmediği durumda oluşur. Boş meyveler, çeşitlere, çeşit $\mathrm{x}$ yll interaksiyonuna ve bir ağaçtaki örneklere göre bile çok değişim gösterebildiği ve bu özelliğin kalıtım derecesinin \%50'nin üzerinde olduğu belirtilmektedir (Mehlenbacher ve ark., 1993). 'Çakıldak' çeşidinde dekara verim ile boş meyve arasında önemli negatif ilişki belirlenmiştir (Bozkurt ve Bostan, 2018).

Boş meyvelerde içler ya baştan itibaren gelişmeden geri kalır ya da gelişmeye başladıktan sonra, özellikle de erken gelişme safhasında, abortif olurlar. Bazı içler normal iriliklerinin yarısından daha fazla gelişip sonra buruşabilirler. Böyle küçük içler de boş meyve olarak değerlendirilirler (Anonim, 2002). Literatürde boş fındıkların iç dokusu solgun, içinde gelișmemiș iki tohum taslağı ve yeșilimsi kabukları olan bir yapıya sahip olduğu şeklinde tanımlanmıştır (Germain, 1994).

Lagerstedt (1977) findıkta boș meyve olușumunun nedenlerini, sitomiksis (mikrosporojenez sirasinda yüksek derecede görülen kromozomal sapmalar), genetiksel uyumsuzluk (çeşitlere göre değişim ya da uyumsuz tozlayıcı çeşit), kendine tozlama, anöploidi (türe özgü kromozom sayısından bir fazla veya bir eksik kromozom sayısının görülmesi), çift döllenme eksikliği (polar endosperm çekirdeğinin döllenmesi ancak yumurta ana hücresinin döllenmemesi ya da yumurta ana hücresinin döllenmesi ama polar çekirdeğin döllenmemesi), mevsimsel değişimler ve kültürel uygulamalar (özellikle gübreleme, sulama ve hastalı ve zararlılarla mücade noksanlığı) olarak sıralamıştır. 
Tozlanma eksikliği asla boş fındık oluşumunun nedeni değildir, çünkü tozlanmamış bir çiçek bir meyve geliştirmeye başlamaz. Dişi çiçeklerin örtülmesi ile polenlerden korunması durumunda çiçekler kurur ve nisan ayının sonunda veya mayıs ayının bașında düşerler (Anonim, 2002). Kendilemenin, tozlayıcı çeşitlerin ve serbest tozlanmanın boş meyve oluşumu üzerine etkisinin önemli olduğu ve bu durumun çeşitlere, kombinasyonlara ve yıllara göre değiştiği; karanfilin çotanağa dönüşüm oranının az olduğu uygulamalarda boș meyve oranının yüksek olduğu belirlenmiştir (Balık, 2019).

Boş meyve oluşumuna yüksek oranda katkıda bulunan faktörler kesin olarak belirlenmemekle beraber yaz ortasında toprak neminin yetersiz olması, tozlayıcı çeşit, yetersiz ağaç beslenmesi, aşırı büyümüş ağaçların olduğu bahçelerdeki düşük ışık seviyeleri ve ana çeşit gibi olasılıklar üzerinde durulmaktadır (Anonim, 2002).

$\mathrm{Bu}$ boş meyvelerin zurufu ile birlikte düşmesi, kahverengi lekeli durumda temmuz ayının başından itibaren ve boş findık oluşumundan bir ay sonra ortaya çlkar ve hasat boyunca devam eder. Bu düşmüş çotanaklar çoğunlukla tekli ya da ikili olup büyük bir kısmı sağlıklı fındıklara sahip olan çotanaklar dökülmezler. En ağır durumlarda bu kayıplar ürünün yüzde 80'ine ulaşabilir (Stebbins, 1984).

Dimoulas'a (1979) göre döllenme eksikliği bu bozukluğun nedeni değildir. Dimoulas, boş meyvelerin en az bir döllenmiş tohum taslağı içerdiğini gösterdi. Bununla birlikte, Lagerstedt (1977) boş meyve oluşumunun bir nedeni olarak ya yumurta hücresi veya polar çekirdeğinin çift döllenme eksikliğini ifade etmektedir. İkinci durumda, albümen eksikliği embriyo aborsiyonu oluşturur. Öte yandan, çeşitli Corylus avellana L. çeşitlerinde kromozomal sapmalar, özellikle de mikrosporlar oluştuğunda heterozigotik bir yer değiştirme mevcudiyeti gözlemlenmiștir. $\mathrm{Bu}$ tür değişimlerin dişi gametler oluşturulduğunda meydana gelebileceği ve bu nedenle yumurta hücresinin işlevsel olmadığı için döllenemeyebileceği öne sürülmüștür.

Boş meyve oranı bakımından çeşitler arasında önemli farklılıklar vardır. Bazı çeşitlerde yüksek olması kromozomal ya da sitogenetik anormalliklerden kaynaklanmaktadır (Mehlenbacher, 1991). Öte yandan, Dimoulas (1979), yumurtalık başına tohum taslağı sayısının ve özellikle meyve başına döllenmiş tohum taslağ sayısının, bazı boş meyvelerin oluşumu üzerinde büyük bir etkisi olduğunu göstermiştir (Germain, 1994).

Çotanakta meyve sayısı (Dimoulas, 1979) ve meyve sürgünlerinin uzunluğunun boș meyve oranını etkilemediği belirtilmiştir. Germain (1994) findıkta boş meyve oluşumu üzerinde genetik faktörler, kültürel uygulamalar ve iklimsel faktörlerin etkili olduğunu bildirmiştir.

Portekiz'in en fazla üretilen çeşidi olan 'Butler' da boş meyve oluşumunun nedenlerini araştırmak için, boş meyve oranları her yıl nisan ayından temmuz ayına kadar iklim faktörleri (sıcaklık, yağıș, güneş ışığı, rüzgâr ve bağıl nem) ile ilişkilendirilmiştir. Çalışma sonucunda, findıkta döllenme aşamaları bakımından mayıs ayının en hassas ay olduğu; en sıcak ay olan temmuz ayındaki en yüksek minimum sıcaklıklar ile ilgili olarak güneş ışığının daha yüksek seviyeleri ve düşük nispi nemin boş meyve sayısındaki azalmaya katkıda bulunduğu belirlenmiştir (Silva ve ark., 1996).

Bunların yanında, aşırı büyümüș bahçelerdeki düşük ışık seviyeleri de boş meyve oluşumu üzerine etkili olabilmektedir (Olsen, 2013). Zira fındık ağacının gölgede kalan kısımlarında çotanak dökümü ve boş meyve oranı daha fazla olarak belirlenmiştir (Valentini ve ark., 2009). 'Tombul' ve 'Palaz' çeşitlerinde de bahçelerin güneşlenme düzeyleri azaldıkça boş meyve oranlarının önemli oranda arttığı belirlenmiştir (Şen ve Bostan, 2020).

Bazı kültürel uygulamaların boş meyve oranını etkilediği görülmektedir. Su eksikliği bu tür meyvelerin yüksek bir seviyesi ile ilişkili olabilir (Germain, 1994). Külahçilar ve ark. (2018) 'Tombul' çeşidinde sulamanın boş meyve oranını azalttığını belirlemişlerdir. Ayrıca, toprak tipinden de etkilenir. Farklı gübrelemelerin fındıkta boş meyve oluşumuna etkisine dair sonuçlar arasında da farklılıklar bulunmaktadır. Azot, fosfor ve magnezyum eksikliklerinin boş meyve oluşumuna etkisinin olmadığı; iyi bir potasyum beslenmesinin boş findık sayısını azalttığı (Germain, 1994); 'Palaz' findık çeşidinde farklı azot dozlarının sağlam iç oranı ve boş iç oranı üzerine etkisinin istatistik olarak kontrolden farklı olmadığı (Beyhan ve ark., 1998); bor uygulamasının boş meyve oranını azalttığı (Baron ve ark., 1985); 'Tombul' çeşidinde yapraktan borik asit ve topraktan boraks uygulamaları ile suni tozlama ile azot, fosfor, potasyum ve bor uygulamalarına ait kombinasyonların boş meyve oluşumunu azaltmada etkili olduğu (Okay ve ark, 1987); 
yapraktan bor uygulamasının boș meyve olușumuna etkisinin önemli olmadığı hatta bor uygulamalarında bir artış eğilimi olduğu (Silva ve ark., 2003); B-Zn gübresinin (\% 10 B, \% 4 Zn) 'Çakıldak' ve 'Tombul' fındık çeşitlerinde boş meyve oranına sadece ilk yıl önemli etki ettiği ve en düşük oranların 150 g/ocak uygulamasında elde edildiği (Serdar ve ark., 2005); 'Tombul' çeşidinde yapraktan bor uygulamasının boş meyve, kusurlu meyve, çotanaktaki meyve sayısı ve randıman üzerinde bir etkiye sahip olmadığı (Erdogan ve Aygun, 2009) belirtilmiştir.

C. heterophylla Fisch türünde yaprak azaltma ve bilezik almanın boș meyve oranına etkisinin önemli olduğu, en düşük oranı kontrol grubunda bilezik alma uygulamasında, en yüksek oran da \%100 yaprak azaltmanın bilezik alma uygulamasında olduğu belirlenmiştir (Liu ve ark., 2012).

Milosevic ve Milosevic (2012) sağlam iç oranının çotanak dökümü arttıkça belirgin şekilde arttığını fakat boş findık oranının önemli ölçüde azaldığını belirtmişlerdir.

Boş meyvelerin oluşması findık yetiştirilen her yerde ve her çeşitte dikkate alınmaktadır. Belirli bir çeşit için, bu oran yıldan yıla değişirken \% 25'e kadar varabilmektedir. Bu durum üründe ciddi kayıplar meydana getirirken, diğer taraftan, bunların sağlam ürünlerden ayıklanması gibi, ekstra bir iş gücü gerektirmektedir. Aksi takdirde bunun bedelini üretici ödemek durumunda kalmaktadır (Lagerstedt, 1977).

\section{Eksik (abortif) ve buruşuk iç}

Eksik içler \% 25'ten daha fazla dolgunluğa sahip ama kabuk içi boşluğunun \% 50'den daha az olduğu durumdur. Buruşuk meyveler içte bazı çökmüş alanlara sahiptir. $\mathrm{Bu}$ durum aşırı yüksek sıcaklıklarda hızlı iç büyümesine bağlanmıștır. Böyle içlerin yüzeyinin \% 50'sinden fazlasında buruşukluk vardır. İç gelişimi sırasında ağaçları strese sokan herhangi bir çevresel faktör boş, eksik içli ve buruşuk içli meyvelerin sayısını artırmaktadır. $\mathrm{Bu}$ faktörler arasında düşük toprak verimliliği, zayıf ağaç beslenmesi, olumsuz iklim koşulları (kuraklık veya yoğun sıcaklık gibi), yetersiz ıșıklanma veya ağır ürün yükü sayılabilir. Eksik ve burușuk içlerin oranı büyük meyveli çeşitlerde daha yüksektir. Bakteriyel yanık da buruşuk içlerin görülme sıklığına da neden olmuştur (Mehlenbacher, 1991; Anonim, 2016). Eksik iç oluşumunda yılın da fazla etkisi görülmüştür (Mehlenbacher ve ark., 1993).
Buruşukluk büyük oranda meyve iriliğiyle ilgili olup büyük meyvelerde buruşma küçük meyvelerden daha fazla olmaktadır. Bununla beraber, irilik dışında, buruşukluk aynı zamanda genetiksel bir özellik olup bu da hücre büyüklüğü ya da yağ içeriği gibi hücrenin bileşimi ile ilgili olabilir (Thompson ve ark., 1996)

Beyhan ve Marangoz (1999) 'Tombul' ve 'Palaz' çeşitlerinde buruşuk iç oranlarının yıllara göre değişiminin istatistik olarak önemli olmadığını, bu oranların 'Tombul' çeşidinde daha düşük olduğu ve bunun nedeninin de kendine ve diğer çeșitlerle olan eşeysel uyuşma düzeylerinden kaynaklanabileceğini ifade etmişlerdir. 'Tombul' çeşidinde buruşuk iç oranının rakıma göre değişiminin önemli olmadığ fakat iç ağırlığı ile buruşuk iç oranı arasındaki ilişkinin negatif ve önemli olduğu bulunmuştur (Bostan, 2003; Karadeniz ve Bostan, 2006).

'Palaz' fındık çeşidinde farklı azot dozlarının buruşuk iç oranı üzerine etkisi, istatistik olarak kontrolden farklı olmamıştır (Beyhan ve ark., 1998).

B-Zn gübresi (\%10 B, \%4 Zn) 'Çakıldak' ve 'Tombul' findık çeşitlerinde buruşuk iç oranına her iki yıl önemli etki etmiş ve en düşük oranlar $150 \mathrm{~g} / \mathrm{ocak}$ uygulamasında elde edilmiştir (Serdar ve ark., 2005). 'Tombul', 'Palaz' ve 'Çakıldak' çeşitlerinde buruşuk iç oranının çeşitlere ve yıllara göre değiştiği belirlenmiştir (Serdar ve Demir, 2005).

Eksik iç yüzdesi gölgeleme artılkça artmaktadır (Hampson ve ark., 1996). Zira Şen ve Bostan (2020) da 'Palaz' çeşidinde bahçelerde güneş ışığı azaldıkça kusurlu içlerin arttığını, 'Tombul' çeşidinde de böyle bir eğilimin olduğunu ama istatistik olarak önemsiz olduğunu belirtmektedirler.

Fındıkta kendilemenin, tozlayıcı çeşitlerin ve serbest tozlanmanın buruşuk iç oranı ve abortif iç oranı üzerine etkisinin önemli olduğu ve bu durumun çeşitlere, melezleme kombinasyonlarına, yıllara, meyve yüküne, erken hasada, beslenme ve su yetersizliğine bağlı olarak değiștiği belirtilmiștir (Balık, 2019).

\section{Büyük göbek boșluğu}

Fındıkta meyvelerin içinin dolgun ve özellikle kurutmadan sonra küçük göbek boşluklu olması istenilmektedir (Lagerstedt, 1975). Göbek boşluğunun, her ne kadar birçok faktöre göre değişse de, genel olarak kalıtsal olduğu düşünülmekte ve aynı zamanda kabuk inceldikçe artmaktadır (Çetiner ve ark., 1984). 
'Yassı Badem', 'Foşa' ve 'Mincane' çeşitlerinde göbek boşluğu değerinin kurutma ortamlarına göre değişimi önemsiz çıkarken, çeşitlere göre değişimi önemli çlkmış ve en yüksek değer 'Mincane' çeşidinde belirlenmiş, diğer iki çeşit aynı grupta yer almıştır (Bostan, 1999).

'Tombul' çeşidinde göbek boşluğunun rakıma göre değişiminin önemli olduğu ve orta kuşaktaki değerlerin daha düșük olduğu belirlenmiștir (Karadeniz ve Bostan, 2006).

'Tombul', 'Palaz' ve 'Kalınkara' çeşitlerinde findıkların zuruflarindan elle ve patozla ayıklanmasının göbek boşluğuna etkisinin araştırıldığı bir çalışmada, sadece 'Kalınkara' çeşidinde uygulamanın etkisinin önemli olduğu ve patozla ayıklanan findıklarda boşluğun daha büyük olduğu belirlenmiştir (Akar ve Bostan, 2018).

'Çakıldak' çeşidinde göbek boşluğunun verimle ilișkisi önemsiz bulunmuștur (Bozkurt ve Bostan, 2018).

'Tombul' çeşidinde göbek boşluğu büyüklüğü sulamaya göre değişmemiștir (Külahçilar ve ark., 2018)

'Palaz' çeşidinde bu değer bahçelerin güneşlenme durumuna göre önemsiz çlkarken, 'Tombul' çeşidinde önemli çıkmış ve en yüksek değer günün yarısında güneşli olan bahçede, en düşük değer de tam gün güneșli bahçede belirlenmiştir (Şen ve Bostan, 2020).

\section{Çift iç}

Çift içler (bir kabuklu meyve iki iç meyvenin gelişimi), küçük boyutları ve düzensiz şekilleri nedeniyle istenmezler. Bazı çeşitlerde, çift iç oranı önemli bir ekonomik kayba neden olacak kadar yüksektir (Thompson ve ark., 1996).

Çift içler bazen birbiriyle aynı bazen de farklı irilikte olabilir. Çift içlilik büyük oranda bir çeşit özelliğidir fakat yıldan yıla da dalgalanma gösterir (Mehlenbacher, 1991). Çift içler her iki yumurtalığın eş zamanlı döllenmesi ve gelişmesiyle ortaya çlkmakta olup büyük oranda bir çeşit özelliği olup yıldan yıla da dalgalanma gösterebilmektedir (Mehlenbacher ve ark., 1993). Bostan ve Günay (2009) da çift iç oranlarının çeşitlere göre önemli düzeyde değiștiğini bildirmiștir.

'Kalınkara' çeşidinde ikiz içlilik ile çotanaktaki meyve sayısı ve randıman arasında önemli pozitif, meyve eni arasında önemli negatif ilişkiler belirlenmiştir. Çotanaktaki meyve sayısı ile randımanın ikiz içliliğe olan doğrudan etkileri, meyve eninin de iç kalınlığı üzerinden olan dolaylı etkisi daha fazla olmuştur (Bostan, 1997b).

Balık kendilemenin, tozlayıcı çeşitlerin ve serbest tozlanmanın çift iç oluşumu üzerine etkisinin önemli olduğunu ve bu durumun çeşitlere, melezleme kombinasyonlarına ve yıllara göre değiştiğini bulmuştur (Balık, 2019).

\section{Liflilik}

İç fındık üzerinde liflerin bulunmaması, kabuklu ya da natürel iç olarak pazarlanacak meyveler için arzu edilir. Lif iç meyveye acı bir tat verir ve natürel içlerin genel görünümünü bozar. Lif, zarla birlikte tamamen çıkarılabilmesi durumunda, beyazlatılmış veya kavrulmuş fındıklar için bir sorun oluşturmaz. Lifler içi meyvenin kurumasını da yavaşlatır. Ayrıca, eğer lif hem kabuğa hem de kabuğun iç yüzeyine sıkıca yapışırsa, kabuğun çekirdekten ayrılmasını da engelleyebilir (Mehlenbacher, 1991; Anonim, 2016).

İç lifliliğinin kalıtım derecesi orta derecede yüksek $\left(h^{2}=.68\right)$ olarak bulunmuştur. Liflilik sonraki nesilde daha yüksek oranda gözükebilmektedir (Thompson ve ark., 1996).

Fındıkta kendilemenin, tozlayıcı çeșitlerin ve serbest tozlanmanın testa lifliliği üzerine etkisinin düșük seviyede olduğu ve tozlayıcı çeşide bağlı olarak testa lifliliğinde değişikliklerin olabileceği gibi, lifliliğin gözleme dayalı olarak belirlenmesinin yanıltıcı sonuçlara varılmasına sebep verebileceği belirtilmektedir (Balık, 2019).

\section{Siyah uçlu iç}

İç meyvedeki siyah uçlar bazı klonlarda nispeten yüksek frekanslarda ortaya çlkar. $\mathrm{Bu}$ özellik ebeveynlerden bazı soylarına aktarılmaktadır. İnce kabuk yapısındaki ebeveynler zayıf sütur özelliğini döllere geçirmektedir. $\mathrm{Bu}$ yüzden ıslah programlarında hem randımanlı hem de sütur birleşmesi sıkı olan genotiplerin seçilmesi daha çok dikkate alınır. Sorun, kabuklu meyvenin çıtlak olması ya da süturların bağlantısının zayıf olması ile ilişkilidir. Bu durumun sadece zar üzerinde meydana gelen bir oksidasyon sürecinden ortaya çıtığ görülmektedir. Siyah uçlar küflü içler ile ilişkili olabilir veya olmayabilir. Siyah uçlu içler özellikle sütürları iyi birleşmeyen meyvelerde görülür. Ürün yükü az olduğunda iç gelişimi fazla olur. Bu durumda süturlar açılır ve açıkta kalan zar kararır (Mehlenbacher ve ark., 1993).

Siyah uçlar, bazen küflü halde olup iç meyvenin uç kısmındaki doku ölümlerinden kaynaklanır. Ölü 
doku içe birkaç milimetre kadar uzanır. Siyah uçlar, çeşit çalışmalarında iç kusurları olarak listelenmiştir ancak uluslararası standartların hiçbirinde ayrı bir hata sınıfı olarak tanımlanmamıștır. Siyah uçları kapsayacak tek tanımlama "iç renk değişikliği" dir (Anonim, 2016).

Diğer taraftan randıman ile siyah uçlu içlilik arasında pozitif ilişki belirlenmiştir (+0.25) (Mehlenbacher ve ark., 1993).

\section{Küflü iç}

İç mevenin dış veya iç tarafında gözle görülebilir herhangi bir küf gelişimi kusur olarak kabul edilir. Göbek boşluğu yüzeyindeki küf ancak çekirdeğin bölünmesi ile tespit edilebilir. Küf, genellikle aşırı büzüșmüș içler ile ilișkilidir ve mantarlar stresli içleri istila edebilir. Fındıkta küf ile ilişkili mantar türleri Aspergillus spp, Penicillium spp, Cladosporium spp ve Phomopsis spp.'dir. Yurtdıșı araștırmalar, sporların meyve gelişimi boyunca mevcut olabileceğini ancak meyvede mutlaka gelişmeyeceğini ortaya çıkarmıştır. Aflatoksin ürettiği bilinen Aspergillus flavus ve Aspergillus parasiticusare ve bu küflerle bulașmış fındıklar insan tüketimi için uygun değildir. Küf oranı üzerindeki ana etkiler, çeşitlerin küflenmeye duyarlılıklarında önemli farklılıklar bulunan çeşitlilik ve iklimdir. Küf, ilkbaharda yağışlı havalardan sonra veya hasat sırasında en yüksektir. Sıcak nemli koşullar, bu küflerin büyümesini kolaylaştırır ve yetiştiricilerin, hasat ve hasat sonrası dönemde findıkların nemli koşullarda tutulmamasını sağlamaları gerekir. Meyve bahçesi yönetimi ile küf kontrolü zordur. İlkbahar, sonbahar ve kışın fungisit spreyleri kullanımı küf oluşumunu azaltamada çok etkili olmamıştır. Bunun için ağacın taç kısmını açık tutacak şekilde yapılacak budama küf oluşumunu en aza indirmeye yardımcı olabilir (Anonim, 2016).

Küflü içlerin görülme sıklığı, farklı genotiplere ve farklı yıllara göre önemli ölçüde değişir. Yüksek oranda küflü içlere sahip olan ebeveynler bu kusuru döllerinin bir kısmına iletir. Bu soruna neden olan mantarlar, meyve gelişiminin çok erken bir aşamasında bitki dokularına girerler. Küflü içler, çıtlak meyvelerde olduğu gibi çıtlak olmayanlarda da bulunabilir (Thompson ve ark., 1996). İç küflülüğünün bahçede ve ağaçta gölgeleme arttıkça arttığı belirtilmiștir (Hampson ve ark., 1996). İç küfü raf ömrünü büyük ölçüde kısaltan bir kusur olup (Mehlenbacher ve ark., 1993), bunlar elle sağlam olanlardan ayrılır. Küf çoğunlukla göbek bağını iç fındığın ucuna bağlanma noktasında görülür. Birçok meyvede küf organizmasının görünür bir giriș noktası yoktur ve aslında küf meyve olgunluğundan uzun bir süre önce içlerden izole edilebilir. Zayıf sütur yapısına sahip çeşitlerin içlerinin uçları kararır ve/veya küflenir. Bazı çeşitler küflü içler gibi sık sık siyah içli uçlara sahiptirler (Mehlenbacher, 1991).

\section{Böcek zararlı iç}

Fındık içleri böceklerden zarar görebilir. $\mathrm{Bu}$ zararlılar hem gelişmekte olan hem de olgunlașmış iç meyveyle beslenirler. Hasar, saldırı zamanına bağlıdır. Eğer meyve kabuğu hala yumuşaksa ve iç hala gelişiyorsa, iç meyve deforme olabilir ve/veya iç meyvenin yüzeyinde kahverengi lekeler belirebilir. İçte istenmeyen bir tat oluşur. Eğer saldırı kabuk sertleștikten ve iç tamamen geliștikten sonra meydana gelirse, hasar beyaz beyaz noktaların gelişimi ile sınırlı olabilir, bazen merkezde iğne ucu kadar bir siyah nokta olabilir. Bu beyaz alanlar, içler kavrulduğunda koyulaşır. Hasarlı içler normal içlerden daha kolay kokar hale gelir. Natürel içlerde, özellikle de lifli olduklarında, meyve zarar görmediğinde ya da zararlı bölgede küf oluşmadığında hasarı tespit etmek zordur. İçler beyazlatıldığında böcek hasarı belirginleşir (Anonim, 2016).

\section{Sonuç}

Fındıkta gerek kabuklu ve gerekse iç meyvede oluşan kusurlar telafisi mümkün olmayan sonuçlara sebeiyet verebilmektedir. Kusurlu meyvelerin oluşması hem hasat öncesi, hem hasat ve harman aşaması hem de depolama sürecini kapsayabilmektedir. $\mathrm{Bu}$ nedenle öncelikle bu kusurların ve oluşum nedenlerinin bilinmesi ve sonra bunlara karşı önlemlerin zamanında alınması hem üretici, hem sanayici hem de tüketiciler bakımından son derece önemlidir.

Bunun için, mevcut bahçelerde findıkta düzenli, bol ve kaliteli ürünü elde etmek için, ağaçların yıl boyunca bakımlarının yerinde ve zamanında yapılması özellikle nisan ayından ağustos ayına kadar olan süreçte bitkiyi strese sokan koşulların ortadan kaldırılması, düzenli bahçe tesisi, budama, ilaçlama, gübreleme ve sulama gibi uygulamalara özen gösterilmesi gerekmektedir. Diğer taraftan yeni bahçe tesislerinde ekolojiye göre çeșit seçimi, uygun tozlayıcı çeşit seçimi, doğru fidan kullanılması, doğru yer seçilmesi, doğru dikim ve terbiye sisteminin uygulanması gibi konulara da dikkat edilmelidir. 


\section{Kaynaklar}

Akar, A., Bostan, S.Z., 2018. Variations in quality traits of 'Tombul', 'Palaz' and 'Kalınkara' hazelnuts separated from husks by husker and hand. Acta Horticulturae, 1226: 345-349.

Akçin, Y., Bostan, S.Z., 2018. Variations in some traits affecting yield in different hazelnut cultivars. Acta Horticulturae, 1226: 149-152.

Anonim, 2002. Growing hazelnuts in the Pacific Northwest. Oregon State University Extension Service, EC 1219

Anonim, 2016. Guidelines for Growing Hazelnuts in New Zealand Bulletin 4: Nut Development and Quality. Murray Redpath. May 2016.

Balık, H.İ., 2019. Fındıkta kseni ve metakseni üzerine araştırmalar. (Doktora Tezi). Ondokuz Mayıs Üniversitesi, Fen Bilimleri Enstitüsü, Bahçe Bitkileri Anabilim Dalı.

Baron, L.C., Rigget, C., Stebbins, R.L., 1985. Growing hazelnut in Oregon. Ed. Oregon State University Extension Service, $20 \mathrm{p}$.

Beyhan, N., 1995. Findıkta, yumurtalık, tohum taslağı ve embriyo gelişimi. Türkiye II. Ulusal Bahçe bitkileri Kongresi, 3-6 Ekim 1665 Adana, Cilt I Meyve, s: 489-493.

Beyhan, N., Demir, T., Sürücü, A., 1998. Farklı Azot Dozlarının Palaz Fındık Çeşidinde Verim, Meyve Kalitesi ve Beslenme Üzerine Etkisi. O.M.Ü.Z.F., Dergisi, 13(1):1-13.

Beyhan, N., Demir, T., 2001. Performance of the local and standard hazelnut cultivars grown in Samsun province, Turkey. Acta Horticulturae, 556: 227 233.

Beyhan, N., Marangoz, D., 1999. Fındıkta Boş Meyve Oluşumunun İncelenmesi. Turkiye lll. Ulusal Bahçe Bitkileri Kongresi, 14-17 Eylül Ankara, Sayfa: 585589.

Bostan, S.Z., 1997a. Tombul, Palaz ve Sivri Findık Çeşitlerinde Çotanaktaki Meyve Sayısı ile Diğer Bazı Özellikler Arasındaki İlişkilerin Belirlenmesi. YYÜZF Tarım Bilimleri Dergisi, 7: 23-27.

Bostan, S.Z., 1997b. Kalınkara Fındık Çeşidinde Kusurlu Meyve Oluşumu ve İkiz İçlilik ile Bazı Meyve Özellikleri Arasındaki İlișkiler. YYÜZF Tarım Bilimleri Dergisi, 7: 1-5.

Bostan, S.Z., 1999. Farklı Ortamlarda Kurutulan Fındıklarda Bazı Önemli Kalite Özellikleri Üzerine Bir Araștırma. BAHÇE, 28 (1-2): 73-78.

Bostan, S.Z., 2003. Important Chemical And Physical Traits And Variation In These Traits In 'Tombul' Hazelnut
Cultivar At Different Elevations. Grasas Aceites 54(3): 234-239.

Bostan, S.Z., Günay, K., 2009. Variation of Important Quality Characteristics in Hazelnut at Different Years and Correlations between Husk Number and Nut and Kernel Traits. Acta Horticulturae, 845: 641-646.

Bostan, S.Z., İslam, A., 1999. Some Nut Characteristics and Variation of These Characteristics Within Hazelnut Cultivar Palaz. Turkish Journal Of Agriculture and Forestry, 23: 367-370.

Bozkurt, E., Bostan, S.Z., 2018. Variation in yield of 'Çakıldak' hazelnut at different elevations and years. Acta Horticulturae, 1226: 157-160.

Bozkurt, E., Bostan, S.Z., 2019. 'Çakıldak' Fındık Çeșidinde Rakıma Göre Kusurlu Meyve ve Sağlam İç Oranlarının Değişimi. Ordu Üniv. Bil. Tek. Derg., 9 (1): 18-26.

Çetiner, E., Okay, A.N., Baș, F., 1984. Yuvarlak pomolojik fındık grubunda çeşit ve tozlayıcı ön seçimi. Sonuç Raporu. Tarım Orman ve Köy İșleri Bakanlığı, Proje ve Uygulamaları Genel Müdürlüğü, Fındık Araştırma ve Eğitim Merkezi Müdürlüğü, $54 \mathrm{~s}$, Giresun.

Dimoulas, J., 1979. Etude de divers aspects de la reproduction sexuee chez le Noisetier, (Corylus avelland). These Docteur-Ingenieur, Univ. Bordeaux II, $162 \mathrm{pp}$

Erdogan, V., Aygun, A., 2009. Effect of Foliar Boron Application on Fruit Set in 'Tombul' Hazelnut. Acta Horticulturae, 845: 331-336.

Germain, E., 1994. The reproduction of hazelnut (Corylus avellana L.): A review. Acta Horticulturae, 351: 195-209.

Hampson C.R., Azarenko A.N., Potter J.R., 1996. Photosynthetic rate, flowering and yield component alteration in hazelnut in response to different light environments. Soc. Hort. Sci., 121(6): 1103-1111.

Karadeniz, T.; Bostan, S.Z., 2006. Tombul Fındık Çeşidinde Meyve ve Toprak Özelliklerinin Rakıma Göre Değișimi ve Bunlar Arasındaki İlişkilerin Belirlenmesi. 3. Milli Fındık Şurası.10-14 Ekim 2004. S: 471-477. Giresun İl Özel İdare Müdürlüğü.

Külahçilar, A., Tonkaz, T., Bostan, S.Z., 2018. Effect of irrigation regimes by mini sprinkler on yield and pomological traits in 'Tombul' hazelnut. Acta Horticulturae, 1226: 301-307.

Lagerstedt, H.B., 1975. Filberts. Advances in Fruit Breeding, (Edited by Jules Janick and James N. 
Moore) Purdue Univ. Press, West Lafayette, p: 456489.

Lagerstedt, H.B., 1977. The occurrence of blanks in the filbert Corylus avellana L. and possible causes. Economic Botany, 31 (2): 153-159.

Latorse, M.P., 1981. Etude de deux facteurs limitant la productivite du noisetier (Corylus avellana L.): Incompatibility pollinique, fruits depourvus d'amande. D.E.A. Univ. Bordeaux II, 52 pp.

Liu, J., Cheng, Y., Yan, K, Liu, Q., 2012. An investigation on mechanisms of blanked nut formation of hazelnut (Corylus heterophylla Fisch). African Journal of Biotechnology Vol. 11(30), pp. 7670-7675.

Mehlenbacher, S. A., Smith, D. C., K. Brenner, L., 1993. Variance Components and Heritability of Nut and Kernel Defects in Hazelnut. Plant Breeding 110, 144-152.

Mehlenbacher, S.A., 1991. Hazelnuts (Corylus). In: Moore, J.N., Ballington, J.R. (eds) Genetic Resources in temperate fruit and nut crops. Acta Horticulturae, 209: 789-836.

Milosevic, T., Milosevic, N., 2012. Cluster drop phenomenon in hazelnut (Corylus avellana L.). Impact on productivity, nut traits and leaf nutrients content. Scientia Horticulturae 148: 131-137.

Okay, A.N., Koç, N., Kılavuz, F.H., 1987. Boș findık olușum sebepleri ve giderilmesi üzerine araștırmalar. Sonuç Raporu. T.C. Tarım, Orman ve Köyişleri Bakanlığı, Proje ve Uygulama Genel Müdürlüğü, Fındık Araştırma ve Eğitim Merkezi Müdürlüğü, Giresun.

Olsen, J., 2013. Growing hazelnuts in the Pacific Northwest. Pollination and nut develpoment. Extension Service, Oregon State University.

Sathuvalli, V.R., Mehlenbacher, S.A., Smith, D.C., 2010. Response of Hazelnut Accessions to Greenhouse Inoculation with Anisogramma anomala. HORTSCIENCE 45(7):1116-1119.

Serdar, Ü., Demir, T., 2005. Yield, cluster drop and nut traits of three Turkish hazelnut cultivars. HORT. SCI. (PRAGUE), 32, 2005 (3): 96-99.

Serdar, Ü., Horuz, A., Demir, T., 2005. The Effects of B-Zn Fertilization on Yield, Cluster Drop and Nut Traits in Hazelnut. Journal of Biological Sciences 5 (6): 786-789.

Silva, A.P., Ribeiro, R.M., Santos, A., Rosa, E., 1996. Blank fruits in hazelnut (Corylus avellana L.) cv. 'Butler': Characterization and influence of climate. Journal of Horticultural Science, 71(5): 709-720.

Silva, A.P., Rosa, E. and H. Haneklaus, S., 2003. Influence of Foliar Boron Application on Fruit Set and Yield of Hazelnut. Journal of Plant Nutrition, 26 (3): 561569 .

Stebbins, R.L., 1984. What's know about brownstain? Proc. Nut Growers Soc. Oreg. Wash, and B. Columbia, 69, 101-108.

Şen, Y., Bostan, S.Z., 2020. The effect of photosynthetic active radiation on yield and quality traits in 'Tombul' and 'Palaz' hazelnut cultivars. Acta Scientiarum Polonorum Hortorum Cultus (Basımda).

Thompson M.M., Lagerstedt H.B., Mehlenbacher S.A., 1996. Hazelnuts. In: Janick J, Moore JN (editors). Fruit Breeding. Volume 3, Chapter 3, Wiley, New York, pp.125-184.

Turan, A., 2017. Findıkta kurutma yöntemlerinin meyve kalitesi ve muhafazası üzerine etkileri. (Doktora Tezi). Ordu Üniversitesi, Fen Bilimleri Enstitüsü, Bahçe Bitkileri Anabilim Dalı.

Valentini, N., Caviglione, M., Ponso, A., Lovisolo, C., Me, G., 2009. Physiological Aspects of Hazelnut Trees Grown in Different Training Systems. Acta Hort. 845:233-238.

Yaman, İ., 2019. Çarşamba (Samsun) ilçesinde bakımlı ve bakımsız fındık bahçelerinde yetiștirilen 'Çakıldak' çeşidinin verim ve meyve özelliklerinin belirlenmesi (Yüksek Lisans Tezi). Ordu Üniversitesi, Fen Bilimleri Enstitüsü, Bahçe Bitkileri Anabilim Dalı. 